\title{
The Isuochi Artisans: Implications of Traditional Arts and Crafts of Isuochi People for Tourism Development in Abia State, Nigeria
}

\author{
Emeka E. Okonkwo ${ }^{1 *}$, Agbasiere Nnaemeka $D^{2}$, Success Uduafor ${ }^{3}$ \\ ${ }^{l}$ Department of Archaeology and Tourism, University of Nigeria, Nsukka \\ ${ }^{2}$ Department of Travel \& Tourism Management, National Institute for Hospitality and Tourism, Abuja \\ ${ }^{3}$ Admission Office, University of Nigeria, Enugu Campus
}

*Corresponding Author: Emeka E. Okonkwo, Department of Archaeology and Tourism, University of Nigeria, Nsukka

\begin{abstract}
Man overtime has demonstrated good knowledge of her environment, and as such explores environmental resources in other to satisfy his needs. Isuochi is a community in Umunneochi Local Government Area of Abia State that is known to possess skills, which remained distinct with them especially in traditional arts and crafts industries. These artisans are resourceful and productive and are now almost self-sufficient people. However, traditional arts and crafts are gradually going into extinction for two reasons. First, the youths often migrate to urban areas in search of white-collar jobs and thus, the art is left solely in the hands of aged and elderly persons. Secondary, imported and second-hand materials, as well as their cheapness, has made most people not to patronise local crafts. These factors among others gave rise to our interest in documenting the traditional arts and crafts of Isuochi. It is believed that if not documented, over time, the arts would only be remembered in myths and stories as in some African phenomenon. To successfully prosecute the study, ethnographic research method was employed. The researchers also used participant-as-observer. Here, the intents and purpose of the study were made known to local craftsmen work and relevant questions useful for achieving the research objectives were asked. Enlightened Isuochi elders were also interviewed. This paper, therefore, attempts to examine the traditional arts and crafts industries in Isuochi with a view to understanding their implications for tourism development.
\end{abstract}

Keywords: Traditional arts and crafts, Isuochi artisans, Tourism development.

\section{INTRODUCTION}

The notion of an authority and viable traditional indigenous arts and crafts industries in Nigeria sound like a joke to most Nigerian communities; they are yet to understand what benefits exist therein. Nigerian communities are richly blessed with their own indigenous arts and crafts industries, which could help them to grapple with, enhanced their living. The basic truth is that no organizes society can thrive without their indigenous arts and crafts industries.

Isuochi is a community in Umunneochi Local Government Area of Abia State that is known to possess some socio-economic activities, which remained distinct with them through in the field of land acquisition for agriculture but also in traditional Arts and Crafts industries. They were resourceful and productive to the extent that they were almost self-sufficient people. However, traditional art and crafts industries will be seen here as the traditional branch of business, which embodies the knowledge acquired by a particular people or society in their struggle to adapt the natural environment through cultural norms beliefs etc.

It is pertinent to note that these traditional arts and craft industries are always an important aspect of culture. They constitute viable cultural attractions Okpoko and Okpoko (2002) noted that cultural attractions are indispensable components of tourism development schemes. They provide a foundation upon which tourist trade should be built. There is a need to examine and understand these sustaining cultural heritage as a basis for sustainable tourism development. Presently, traditional arts and crafts industries, which could have helped to throw light on the way of life of the people and their early history, are being neglected due to various reasons such as western culture, government attitudes illiteracy, religion, lack of amenities and occupation secrecy. This paper, therefore, attempts to 
The Isuochi Artisans: Implications of Traditional Arts and Crafts of Isuochi People for Tourism Development in Abia State, Nigeria

examine the traditional arts and crafts industries in Isuochi with a view to understanding their implications for tourism development.

\subsection{Objectives of the Study}

This research is geared towards the following objectives:

- To identify and examine traditional arts and crafts industries available in Isuochi community.

- To evaluate the implications of traditional arts and craft industries for tourism development.

- To show and highlight the factors, which have posed serious obstacle to the advancement of these traditional arts and craft industries and suggest strategies for improvement and revival.

\section{RESEARCH METHODS}

The method adopted for this research is an ethnographic approach. Commenting on the importance of ethnographic research Nzei, (1994) note that ethnography is very important in contemporary society's development most especially as the extent tradition cultures are fast disappearing. Ethnography, however, provides articulate its methodological presentation. This makes its discoveries to be relevant to specific methods.

Therefore, in the course of this study, the researchers carried out an ethnographic study on the contemporary life of Isuochi people and this involved the collection of relevant oral information from the knowledgeable elders. The researchers also used participant-as-observer. Here, the intents and purpose of the study were made known to local craftsmen work and relevant questions useful for achieving the research objectives were asked. Enlightened Isuochi elders were also interviewed. On the other hand, pictorial pieces of evidence were used to portrayal our points. Finally, relevant library materials were also reviewed for empirical purposes.

\subsection{Brief Empirical Review: Art and Crafts}

Art has been defined by various scholars, as the days go by, one sees, appreciates and desires pleasure from works of arts without bringing conscious of one's actions and most importantly, its meaning (Onuegbu, 2004:9). Art has been appreciated and recognized as the most certain mode of expression, which humankind has achieved. Art, according to Encyclopedia Britannica (2007) is a visual object or experience consciously created through an expression of skill or imagination. Art can be an experience that can be put into a form that represents or expresses an experience. Art is a creative representation of a subjects matter with hands and brains. Art can be an interpretation representing a symbolization of nature; it can be seen as an instrument of beauty, also the physical externalization of inward or internalized feelings. It is also an instrument. This instrument may be political, used instrumentally for or against people. It can be seen as an intellectual medium, which accommodates deep meanings, which may be spiritual or secular, philosophical or poetic (Ekpo, 1980:191).

Every art form is man-made and unique in its special way. Consequently, in order for a work produced to qualify as art, it must portray a high degree of craftsmanship. Aniakor (1976) sees art as a means of restoring the ideal of human society by what they are able to produce.

Crafts, on the other hand, are those activities that require both artistic and practical skill. Crafts are known to be the most elicit symbols of Nigeria's material and spiritual heritage. They are well integrated into the living patterns of Nigerians and inseparable from our spiritual philosophers. According to the World Book Encyclopedia (2003), they could be seen as prized objects for promotion and preservation of tourism (heritage).

The craft was defined in Advanced Dictionary (2006) as "an activity involving a special skill at making things with the land. This special skill at making things with the hand is an acquired knowledge, which is seen as the entire gamut of cultural products such as ideals/ideologies, beliefs, philosophy; crafts created by human beings in an attempt to understand and master their environment and ultimately manipulate it to their advantages (Okeibunor, 2000). Crafts have been seen as the "creation of objects of hand" (World Book Encyclopedia, 2003). The range of craft is limited only to the individual or group's imagination and ability. In Microsoft Encarta Encyclopaedia (2007), crafts (also handicrafts or handcrafts) were seen as decorative and functional objects made generally by 
hand. Crafts are manufactured for a host of reasons. Many learn crafts as challenging and entertaining hobby; others enjoy expressing artistically and derive satisfaction from making different things. In the past (prehistory), handicrafts served as the only method of creating objects needed since there were no machines.

Crafts could also be referred to as an activity involving a special skill at making things with the hands (an important part of African arts and crafts) for example, traditional crafts like basket weaving etc (Jabbe, 2004:200). Presently, following the increased public interest and the realization of the need to create crafted objects which requires great skill, knowledge and design; in schools and colleges, students are being taught the crafting of objects. Umekekwe (1998) is of the opinion that in order to climb to the higher steps of the technological ladder, there is the imperative need to master our basic crafts and industries, for it is only when this is done that we can develop them, for crafts cannot be divorced from technology. Crafts in Nigeria have been grouped into the following based on their medium: textile, pottery, ceramic, iron-works, fibre crafts, bronze, leatherwork and ivory etc Umekekwe (1998).

\subsection{Background Information on the Study Area}

Isuochi is a town, which lies some twenty-two kilometres on the northern border of Okigwe division low land between Awgu hill in Enugu State, Achi town in Enugu State and Owerre-Ezikala in Orumba South local government in Anambra State. Isuochi is one of the autonomous communities in Umunneochi local government area in Abia State. Isuochi has a population of over 45,000 people, according to the projection by Abia State government 1990 (Abia Census Board, 1990). Among the inhabitants are many immigrant traders, farmers and workers. The land surface of the Isuochi environment lies between latitudes $6^{\circ} 17^{\prime}$ and $7^{\circ} 12^{\prime}$ 'South-South and longitudes $6^{0} 52$ and $7^{0} 54$ East, and cover a total surface area of approximately 3, 962 square kilometres (Abia Census Board, 1990).

There are two climate seasons in the year the rainy (wet) season and the dry season. Isuochi falls within the deciduous forest region the vegetation is predominantly grassland, not essentially savannah with forest in some places. This is so because of the porosity of the soil. The highest temperature in the area is usually recorded between December and March. The mean maximum temperature is about 300 centigrade; while the lowest temperature is usually recorded from June to July (Abia Census Board, 1990).

\section{Presentation of Findings}

Isuochi people have displayed superiority over their immediate environment by making use of what is available to satisfy their needs. Traditional arts and crafts identified and studied are below:

\subsection{Cain Craft/ Weaving}

The art of cain craft/weaving distinguishes Isuochi people from other Igbo communities. Amuda dominated this art of craft weaving exclusively. According to Mr. Chibueze Uba, cain craft/weaving did not originate from Amuda where it is now practised exclusively. This art of cain weaving was said to have been acquired by Emelike Madu from Madu's family in Mbala Isuochi when Uba lived there. However, because Mbala was located near Achara stream where the raw material (cain willow) dominantly grow; they were regarded as cain craft professionals.

There are different steps involved in the production of Cain weaving. Although, men produced them in large quantities. The season at which the demand for it is high is early January to March when schools resume. In the first stage, the raw materials needed for cain weaving is collected from "oga" tree. The cain rope is gotten from the willow either the pillar. It should be noted that cain rope is the one used in designing most of the shapes since all materials always come in a bunch and will be fresh before weaving and can last for four months. In the second stage, which is the weaving process, the inner part of the willow will be cut in pieces, nailing the edges of the cain and tying the head of the craft; followed by the cain rope.

The cain craft could be painted at this stage after the weaving process; to paint these materials, different colours were applied such as red, black, and blue at the bottom or at the top. It takes about 30 minutes for the paint to dry, of which when thoroughly dried, the beauty comes out and it is ready for sale. Many verities of cain craft can serve different purposes. Among them are: 
- Cain Cupboard: This is known as "diamond". It is big in size and it the size. It is mainly used by students both in schools and at homes. It can be put into other uses like storing of provisions, cooking utensils like pots, stoves, plates, cups etc.

- Cain Bed: This is also called 'cannash'. Women mostly use this during the maternity period for newborn babies. It can accommodate more than 6 babies. Due to the nature of the bed, it lasts more than 25 years if the rain did not touch it.

- Cain Chair: This is a very big chair, which comes in sets. It is mostly used at homes for example in sitting rooms. It is also used by couples during traditional marriage and wedding ceremony.

- Cain Basket: This is a smaller size flower basket. It is used in arranging different kinds of powers. It is mostly used in offices, homes and for wedding decoration. They are normally painted in different colours.

- Cain Mirror: This is a medium-sized mirror, and it is mainly used in bedrooms as cosmetics table. It is also used in offices. It is mostly supplied to super-markets, and students buy it.

\subsection{Local Thatch}

Local thatch is another traditional craft Isuochi people are practising. The pre-colonial Isuochi people made use of local thatch in building their mud houses before modernization came into existence with the introduction of aluminium zinc for roofing of houses. The raffia palm tree, which is the most widely used raw material for local thatch, has been part of Isuochi's cultural life. Palm wine is extracted from the raffia palm tree. Some of these materials include; kpkikitimkpi, mkpara arongwo.

During the process of making local thatch, the mpkara is spread two on the ground in a horizontal line, the arongwo (the leaf) is then placed on top of the line from the beginning to the end until a full thatch can be produced.

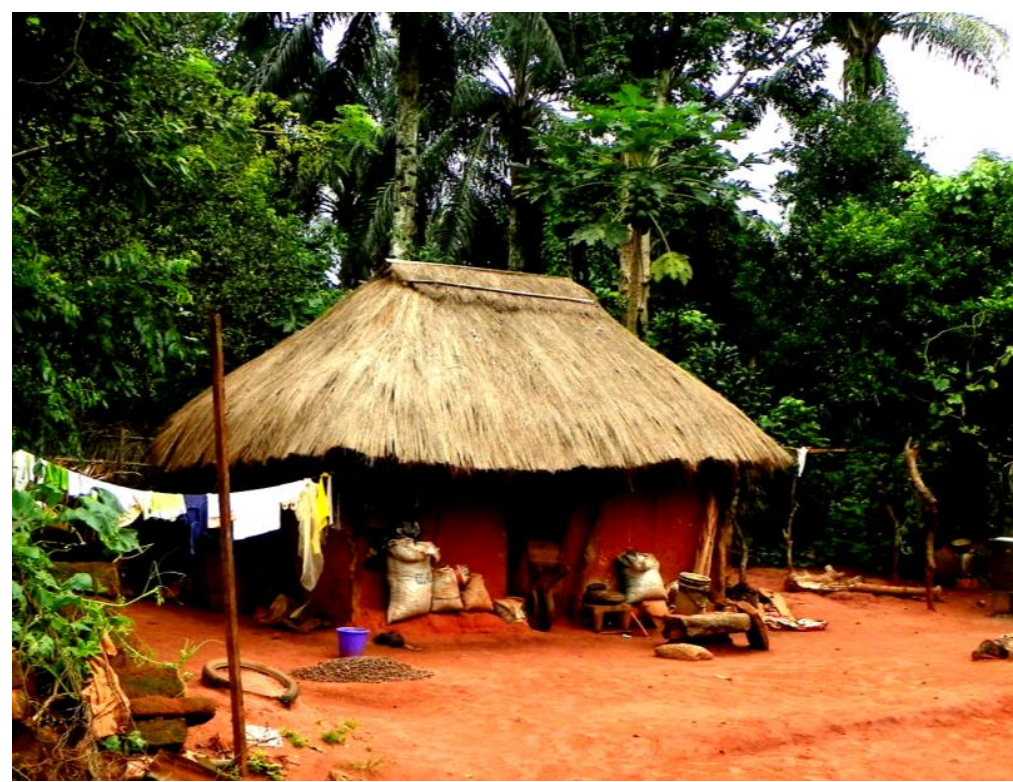

Plate1: A Section of Thatch House

\subsection{Wood Carving}

Carving is the art of visualizing an object in a block of wood, stone, bone and so on and removing bits and clips from the bulk until the desired object is achieved. The practice of woodcarving among Isuochi deities back to their great ancestors. Oral tradition strongly suggested that woodcarving occurred in Isuochi in ancient times. All information continued to point in one direction as the origin of the tradition of woodcarving in Isuochi. They said it is a gift from God to them, and that the tradition was as old as Isuochi town. According to our informant, Mr. Ifeanyi Madubuike who is a carver, "only Obasi nab" the god of artistry can teach and inspire a carver. However, right from the remote past, to the present time, objects carved from wood have always been in abundance in Isuochi homes. 
The basic tools for woodcarving among Isuochi carver right from the beginning to the end of the process comprised the following:

- Adze (Anyuika) is the most important tool for carving. It is used for rough - shaping the wood. The carver does nearly all his work with it.

- Axe (Anyunike), is used in the initial process of cutting down trees, splitting and shaping the logs. In addition, it is used to cut off the size of wood needed for the job.

- Chisel (Akuku Oyiyi) is a metal tool with a very sharp edge at the end of the rod with an attached handle usually made of wood at the top. It is used during finishing touches

- Mallet (Nti) is a type of hammer usually used by the carvers for striking the handle of a chisel. The mallet blows are usually employed during the preliminary roughing -stages.

- Knife $(\mathrm{Nma})$ is used to make incisions or face decorations on the object to be carved; it is used to apply face decorations in the case of a mask such as eyes, nose, facial marks etc.

- Gum is used to hold two pieces of wood tightly together.

- Tape is used to measure the size of wood that would be needed.

- Sandpaper or Broken Bottles and Glasses: This also is included in the tool package of Isuochi carvers and is used to smoothen rough ends or chisel marks to give the job a smooth and fine finishing.

However, the handling and use of the carver's tool depend on each carver. The use of a particular tool is not restricted to a particular function but manipulated and handled by the carver to suite his own choice and convenience. The basic raw material used by traditional carvers in Isuochi is wood. The reason behind the extensive use of wood as a major raw material for carving among Isuochi carvers stems from the fact that wood possesses essential natural qualities suitable for carving. Apart from this, varieties of wood are available, relatively cheap, and economical to get. Lastly, but very importantly, wood is believed to possess animistic power. In other words, the reasons are centre on suitability, availability, cheapness and spiritual powers.

The vegetation of Isouchi is characterized by thick forests, and in these forests are different varieties of woods that can easily be felled and used by the villager for carving. Almost every kind of wood ranging from soft to hardwoods needed for various types of carving is readily available and carvers therefore, rightly took advantage of this. Wood is cheap and in most cases cost of thing except for the labour involved in cutting it down. Because of all these reasons, wood is more attractive to carvers than any other raw materials used for carving (Emejue, 1973). In Igbo land, such tress like Oji, Ogirishi (New bunch leaves), Ogbu (fig tree), Ngwu (Albizia feruzinea) etc are regarded as sacred trees. Ethnographic sources revealed that they pose animistic powers. Such carved figures like masks, ikenga, ritual figures, iroko and all carved objects of religious worship are from these sacred trees (Emejue, 1973). Softwoods varieties abound in the area. These varieties are generally soft, white and course-grained (Emejue, 1973). They are commonly used not only because of their light and soft nature but because they are easy to carve. Apprentice carvers normally start with these types of woods.

TableII: Some Hard and Soft Woods Used in Carving

\begin{tabular}{|l|l|l|l|l|}
\hline S/No & Local Name & English Name & Botanical Name & Categories of Wood \\
\hline 1 & Ogirishi tree & Locust bean tree & Newbondia loueis & Soft \\
\hline 2 & Okwe tree & African oil nut tree & Riciwodendron & Soft \\
\hline 3 & Ogbu tree & Fig tree & Fienus spp & Soft \\
\hline 4 & Akibekee & Coconut tree & Coocs nucifercy & Soft \\
\hline 5 & Oji tree & Iroko tree & Chlorophora excels & Hard \\
\hline 6 & Ugba tree & Oil bean tree & Pentadethra wacrophyll & Hard \\
\hline 7 & Ube tree & Pear tree & Dacryodus edulis & Hard \\
\hline 8 & Icheku tree & Pear tree & Diallului guinees & Hard \\
\hline 9 & Ogbono tree & Pear tree & Irviangia gabonesis & Hard \\
\hline 10 & Akparata & Pear tree & Afzelra Africana & Hard \\
\hline
\end{tabular}

Source: Abia State Ministry of Agriculture (2004) 
Woods are categorized by their own unique features and qualities. The hardwoods are normally heavy; some are red in colour; while others are brownish and dark brown in colour. Softwood is usually light in colour; hardwood is more durable than softwood. The carver does not just use any wood but he knows the best wood that would be suitable for a particular job either soft or hard. For instance, objects like masks (Ihu mmanwu), ikenga (ancestral ofo tree) etc are to be carved using wood from the sacred tree. This will enable the carved object to perform its functions effectively. Mortars and doors are carved using hardwood for durability. Drums, flute, spoon, tray etc are carved out of softwood for portability. However, regardless of the type of wood used, all carvers want to use soft and uniform bodied blocks of woods without any spot (Emejue, 1973).

\section{Process ANd TechniQues of Wood CARVING}

The first thing that comes into the mind of the woodcarver when he has an object to carve is the choice of the type of wood to use in accordance with the type or nature of the proposed object and the function it will perform. The "substances method" of carving is what carvers of Isuochi use during carving. The process involves chopping, cutting, slicing or sandpapering of parts of the wood gotten from the fallen tree which is cut into desired shape and size according to the nature and size of the object to be carved, and also in this stage, the carver uses his tape to get accurate measurements. This wood is rotated while this goes on until it takes rough form or shape of what it is to look like.

In the next stage, there is the removal of splinters and rough edges and the basic tools used here are the chisel and wallet, it is the roughing out stage whereby the chisel is used to knock off the rough edges and then the form is smoothened with the aid of the adze or plain jack.

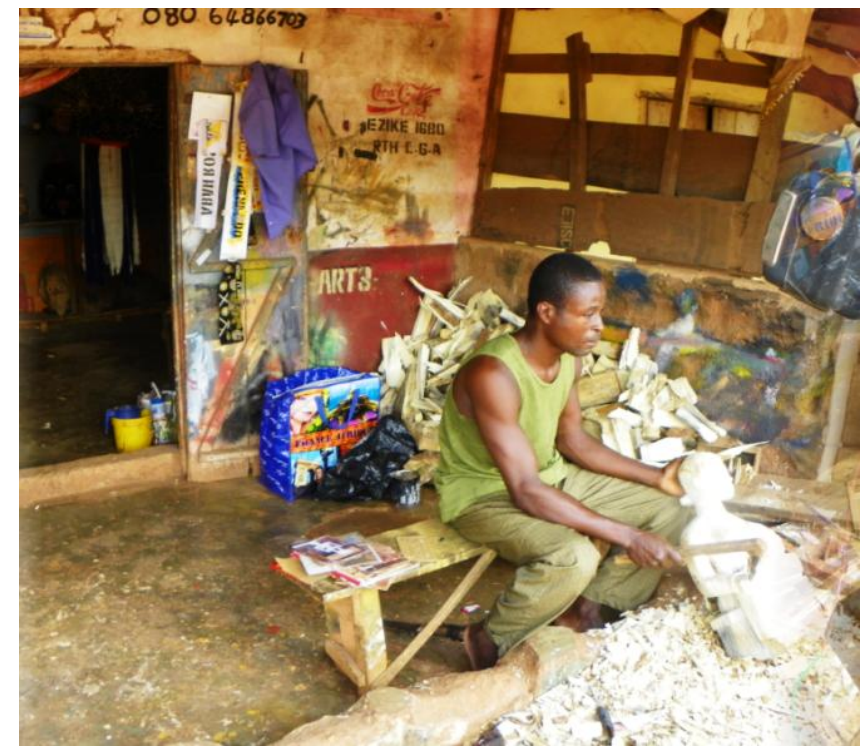

Plate2: A Wood Carver at Work

Chalk (nzu) or charcoal (uyie) is used to draw out the decorations on the object to avoid mistakes made during the incision process and then the small knife and the hands are used for the decorations; at this stage, some carvers still use the chisel and mallet to make decorations. After that, the Adze is still used to smoothen the surface and the chisel is still applied on rough edges. Sandpaper and broken glass are then used to smooth and polish the product to give it a shining look.

In many cases, the carver normally works on a table with an apprentice holding the wood for him as he does the carving, however, in some cases where large objects are being carved the carvers just works on the wood at the position where the wood logs were felled.

\subsection{Carved Products and Their Uses}

Isuochi carvers produce any utilitarian objects, which could conceivably be made of wood that is generally useful for the entire people of the town. This is to say that they carved more useful, functional and practical objects than aesthetically pleasing or attractive objects. These objects are used for religious, ceremonial, domestic and political purposes. Specifically, carved objects and their functions including: 
- Wooden Drum (Igba): Igba is a hollowed wood carved on one end with animal's skin (leather) and fitted to the hollowed wood with ropes. The wood used in constructing 'Igba' is either ' $u g b a$ ' wood or ' $u b e$ ' wood. Igba is a type of drum, which is commonly used by most male and female dancing and masquerade group as an accompanying instrument for their activities. Igba can be played with bare hands or with sticks depending on the nature of the ensemble group.

- Notched flute (Oja): Oja is a traditional flute made from 'ube' wood with a narrowly hollowed cavity, which is cylindrically bored from the top to the bottom. The length is usually about 4 to $16 \mathrm{~cm}$. the width piece is "V" or "U" shaped. It has two finger holes created on opposite sides. There is also a hole at the bottom for another finger position. The Oja adds grace and tempo to the dance. In Isuochi, "Oji onu" and "agba assa", masquerade groups, "Aku n'eche enyi" dancing groups, women dancing groups etc prominently use Oja. Oja is an indispensable musical instrument among the entertainment groups.

- Carved Wooden Door $(A k u)$ : The object is most notable in Isuochi. These sets of doors are actually carved in one or two panels, and they serve as entrances door into domestic house and family compounds. The design and gorgeousness of these doors are symbols of affluence. The hardwood and heavy are those used in carving doors.

- Wooden Tray (Ugbo anu): This is a wooden tray is used in serving food, gifts as well as in gathering meat. Butchers use ugbo anu in gathering cut meats, in their meats shops. This object is usually carved out from oji and 'ugba' wood.

- Mortar (odo): Mortar in Isuochi plays an important role as a kitchen utensil. In Igbo community, mortar is too important to be missed out in any family, which is why it is among the items a girl that is getting married takes to her husband house. This object is for pounding of yam, cassava, palm fruits and for grinding pepper and other ingredients.

There are three main types of mortar, which serves different purposes in every household in Isuochi namely ikwe, odo and okwa. Ikwe is the largest among the mortars. This type of mortar is used for pounding fruits for the production of palm oil. "Odo" is another type of mortar, which comes next in size to "ikwe". It is used for pounding cassava and yam etc. "Okwa" is the smallest in size. It is used for grinding pepper and other ingredients for soup. Due to the functions mortar performs (pounding and crushing) the carvers prefer to use hard and heavy wood to carve the object.

- Wooden Spoon $(E k u)$ : This is a large cooking spoon that has a long handle and then a shallow bowl at the end. It is used for cooking big pots of jollof rice, soups, stews etc. It is very useful in both traditional and modern kitchen.

- Masquerade Mask (Ihu umanwu): Mask production is prominent among Isuochi carves. They carve mask objects for use by indigenes and for outsiders. These carved masks are worn by masquerades during festivals.

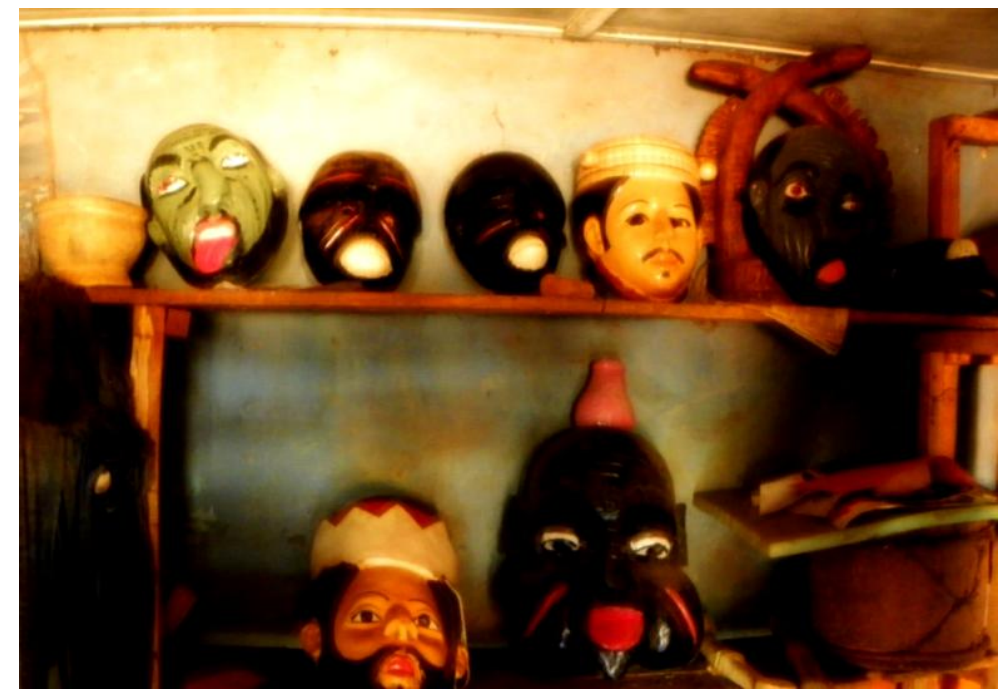

Plate3: Some of the Mask Produced by Wood Caver 
The Isuochi Artisans: Implications of Traditional Arts and Crafts of Isuochi People for Tourism Development in Abia State, Nigeria

\subsection{Blacksmithing Industry}

Blacksmiths involve the use of bloom, which is the product of iron smelting to forge tools or objects. Blacksmithing flourished more than iron smelting because iron smelting flourished only where the raw material, (iron ore) was found in abundance. Presently, iron smelting has gone into extinction; while blacksmithing still flourishes. This is because of importation of iron scrap and availability of discarded iron sheets, which are found most everywhere. Apart from farming, blacksmiths have the widest scope for the practice of their craft than any other craft one may think of. This is because they produce objects like farming implements, kitchen utensils and so on, which are always in constant demand. The art of blacksmiths is practised in many villages of Isuochi, like many other parts of Igbo land such as Awka, Nkwerre, Abariba and so on; but the art was highly developed among the Amuda people. Amuda was synonymous with blacksmiths in Isuochi and Umunne Ochi as a whole. They were excellent blacksmiths and their work spoke for them.

The origin of blacksmiths in Amuda Isuochi has been controversial. There is a school of thought that holds that blacksmiths in the area developed independently; while another school of thought believes that it diffused from outside probably from Nkwerre, Awka or Abiriba. According to the independent or indigenous school of the ought, the difference between the blacksmithing goods, taboos and ritual in Amuda and Awka or Nkwerre suggests independent origin. The diffusionists school of thought believed that the knowledge of iron working could have diffused from Umumeze Amuda, Ngodo and other parts of Isuochi. The argument as to whether blacksmithing developed independently or diffused from elsewhere to Amuda Isuochi is what archaeological evidence and dating can resolve.

Isuochi blacksmiths use varieties of raw materials, which are derived from different sources. The first type of raw material used by Isuochi smiths was local raw materials from traditional iron smelters. According to Onyemaechi Okoronkwo, Isuochi people did not smelt iron, but rather, the sources of their raw materials for blacksmithing in the past were largely dependent on iron bloom, which they obtained from Awka and Nkwerre smiths.

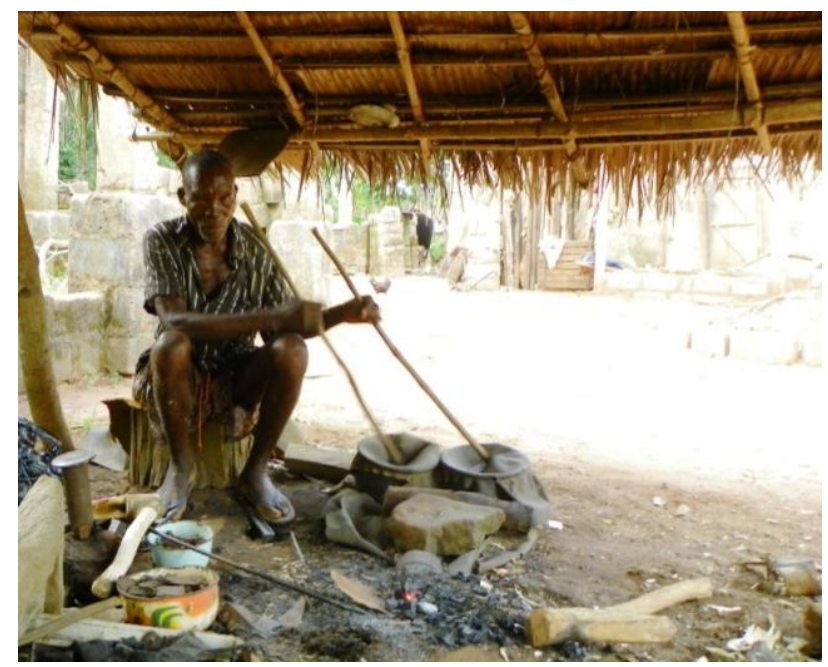

Plate4: Mr. Onyemaechi Okoronkwo in his Workshop

On contact with Europeans, the raw materials for blacksmiths were largely imported into Nigeria, which undermined traditional smelting and encourages the expansion of smithing. Blacksmiths began to decline when we started to be regular customers to the cheap imported finished iron products from Europe. There is no doubt that the competition from cheap imported iron affected the viability of some local industries. Iron bars and various iron products figured prominently in the list of European imports to West Africa during the era of Atlantic trade. Iron bars and manilas are the sources of raw materials for the smithers of Isuochi. The iron bar, about four feet long and roughly an inch thick locally called aka-igwe is also in great demand and supplemented the local supply of iron.

In addition, there was another kind of iron locally called "slippor". This was a large flat long with a quarter-inch thickness and a foot wide. The smiths collected these iron pieces from railway lines. This must have taken place during the construction of Eastern District Railway lines. They travelled as far as Enugu to collect these iron scraps. 
Presently, with the technological development, there are raw materials everywhere. Goucher (1990) argued that too many smiths, the imported metal was inferior and difficult to work with; some blacksmiths preferred to adapt to the new compositions, others were unable and/or refused to work with it. There are iron and steel industries at Ajaokuta, Jos, Oshogbo, Enugu etc. presently, Isuochi smiths buy the bulk of their iron scraps from Onitsha, Awka, Enugu, Nkwerre. These are metal sheets and rods in varying numbers, sizes and thickness and scraps metal from the discarded old vehicle, iron drums and tins which are used for a variety of purpose by Isuochi blacksmiths.

\section{DESCRIPTION OF BLACKSMITH TOOLS}

The blacksmith tools are usually sourced locally, which means that the Isuochi smithers improvise them. The tools are few and are listed as follows: Anvil (Ihuama) is a combination of thick round iron fixed firmly into a $\log$ of wood (ukpaka) measuring about $18 \mathrm{~m}$ in length and about one foot in diameter. Part of the wood is buried inside the ground. Meanwhile, the wood is attached to motortyre. The tyre enables the anvil to vibrate when something strikes on it, thereby prevent rigidly. This is probably one of the major tools of the blacksmiths, as every metal must pass through the anvil during either shaping or hitting.

Hammer (Oti): there are two types of hammers: otutu (hard hammering rod) and obele (light hammer rod). Otutu is a round solid metal with a handle. It is a block-like square rod. The smith had to invite neighbours who help him in shaping it to the desired shape, after series of heating and hammering. $\mathrm{He}$, in turn, prepares a meal as a means of showing gratitude to them. It comes in different shapes and size. Obele, on the other hand, is made of long thick iron with handle. It is lighter in weight when compared with the otutu.

Below $(E k u)$ consists of two wooden or clay pot about a foot diameter from each of which extends a pipe of about $15 \mathrm{~m}$ long. The tops of each hollow vessel are closed with an antelope or goatskin with a light long stick each. These sticks are tied to the skin, which is also used to cover the top of the vessel. The sticks serve as a handle to the below. The below is connected to a clay nozzle attached at both ends of the below. The clay nozzle goes to the heart of the charcoal fire.

Large spoon-shaped (mkpa oku) is a spoon-like shape metal with a long wooden handle of about 1 foot, $6 \mathrm{~m}$ long. It is used for collecting charcoal to and from the furnace.

Poker (Mbache oku) is a long tiny round pipe inserted into a wooden handle; it is about $2 \mathrm{ft}$ long. It is used for turning the red-hot charcoal inside the furnace.

Tong $(M k p a)$ is a plyer shaped metal that is of about 1 foot long. It is used for picking red hot metal out of the fire. It is also used for gripping or holding hot metal; while it is placed on the anvil during hammering. Chisel (Omerigwe) is an iron tool with a very sharp edge at the end of the rod with an attached handle made of wood or rubber and it is used for cold cutting off thin bits.

Punch $(A h a)$ is a round metal rod of various size used for creating a hole on the flat metal sheet.

\section{Production TechniQue}

Forging technique is a practice among the Isuochi Smiths. It involves the use of wrought iron. Wrought iron had the positive features of malleability and ductility. However, by repeated hammering and heating, the iron was strengthened and hardened. The additional separate iron piece was welded together easily at white-heat temperature by hammering. The strongest and most complex shapes were constructed by hammering. In order words, hammering is the technique used to achieve any shape and design required by the smith according to Mr. Onyemechi Okoronkwo.

At first, a scrap of metal was placed at the firm spot and covered with charcoal. The bellow is then blown to apply oxygen to the fire until the metal becomes red-hot. Then the red hot metal is taken out of the fire. This is achieved by the use of mkpa. After that, it will be placed on top of the anvil (ihuama) for shaping, which is usually achieved by hammering. For instance, to produce a hoe, the smith has to heat a piece of iron bar slowly hammered to shape. Due to the size of the fire, there is a restriction on the area of heat, which means the smith had to start from a point, shaping as he goes up the bar. 


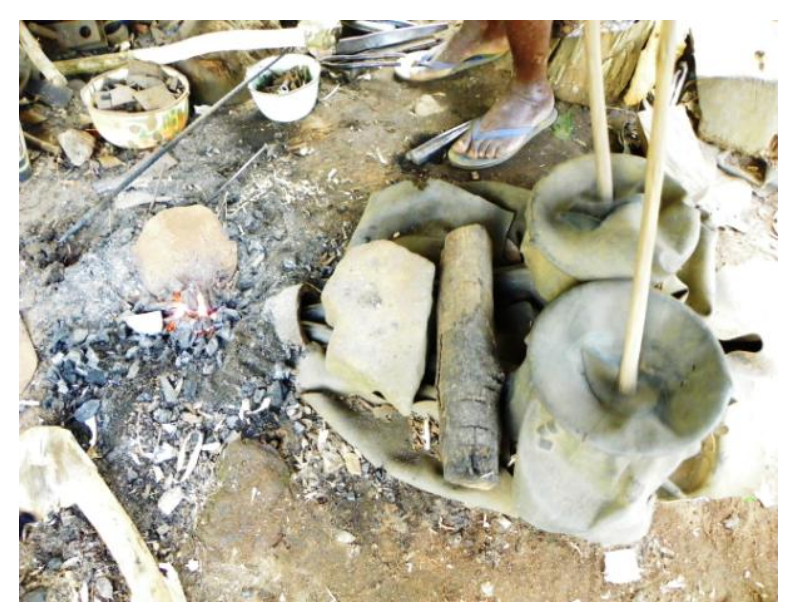

Plate5: Twin Bellows Used in Pumping Air into the Fire Chamber

There is always a repeat heating and hammering of the metal sheet until the desired shape of hoe is achieved, during the process slag is removed out of the fire with a hook poker (mbacha oku); the fire is also tended with flat end poker. The blade of the hoe is circular and thin, but the shafting part is heavier and of course thicker. Protruding bits of red-hot metal is trimmed off with the adze (umunna); while the chisel (owerigwe) is used, for cold cutting off thin bits and the slightly concave hard metal surface is used for shaping the blade of the hoe. The hafting spear-shaped socket was then forced into a wooden handle.

\subsection{Blacksmiths Products and Their Functions}

There is nothing an Igbo smith cannot forge if he is asked to do so (Afigbo, 1981). Isuochi smiths produce any utilitarian objects and their products have quality, durability that is generally used by the entire people of the town and tourists. Their products are items of material culture and will be discussed briefly below

- Economic Products: These are domestic, agricultural and hunting implements. They include tripod (ekwu igwe), kitchen knife (mma ekwu), razor (aguba), axe (anyuike), matchet (mma $i k e$ ), hoe (ogu), metal trap (onyie igwe), spear (aro) etc.

- Leadership/Authority Products: The authority to use power was symbolized in the following products: (mma oji), metal staff and bells, gong (ogene), cannon (mkponala), ring (ola) etc.

- Social Products: Products here underscored ceremonial functions when used in a social context. They include swords (ube), gong (ogene), brass staff (nkpo ala), anket (nja) etc.

- Ritual/Religious Products: These are products for religious and ritual rites; for example, we have a ritual pin (aba igwe), various kinds of a bell (ikpo na mgbirimgba), ritual necklace (onyima), ritual knife (mpoma), scissors (nkpa) etc.

\subsection{Taboos Associated With Blacksmithing}

Since blacksmith is linked with a deity. There are certain rules that must be kept in order not to invite the anger of the gods against the offender. Most of these rules were to be observed in the workshop. In the past, non-smiths do not enter the smiths' workshop without the permission of the owner. It is a serious abomination for women to enter the workshops, except those that had direct blood link with the smiths. It was also, forbidden for women to eat any food prepared in the workshop. It was also a taboo for a menstruating woman to visit the smith's workshop.

Whenever anyone commits any of these offences, the smith raises alarm because it upsets the ritual balance of his life force. Thus, it was always considered a general defilement of the Uzu order (mete ihe uzu); consequently, if such abomination is not removed, it would of course anger the god of iron who would send disaster on the offender. Hence, it was generally believed that the god of iron had the power to set ablaze the house of the offender on fire by the mysterious blowing of the bellow (Eko).

In addition, stealing from the workshop was considered an offence. To appease the deity the offender must provide among other things eight tubers of yam, a gallon of palm wine, eight kola nuts and a 
white cock. The chief priest of the Odufe deity specifically performed purification. Before the smith begins his daily practice, he will first strike his anvil three times with the hammer, this was to ensure the ritual efficiency of his craft. The first strike went to the "ala" (Earth goddess), the second is for the " $u z u$ " spirit and the third for his personal "chi".

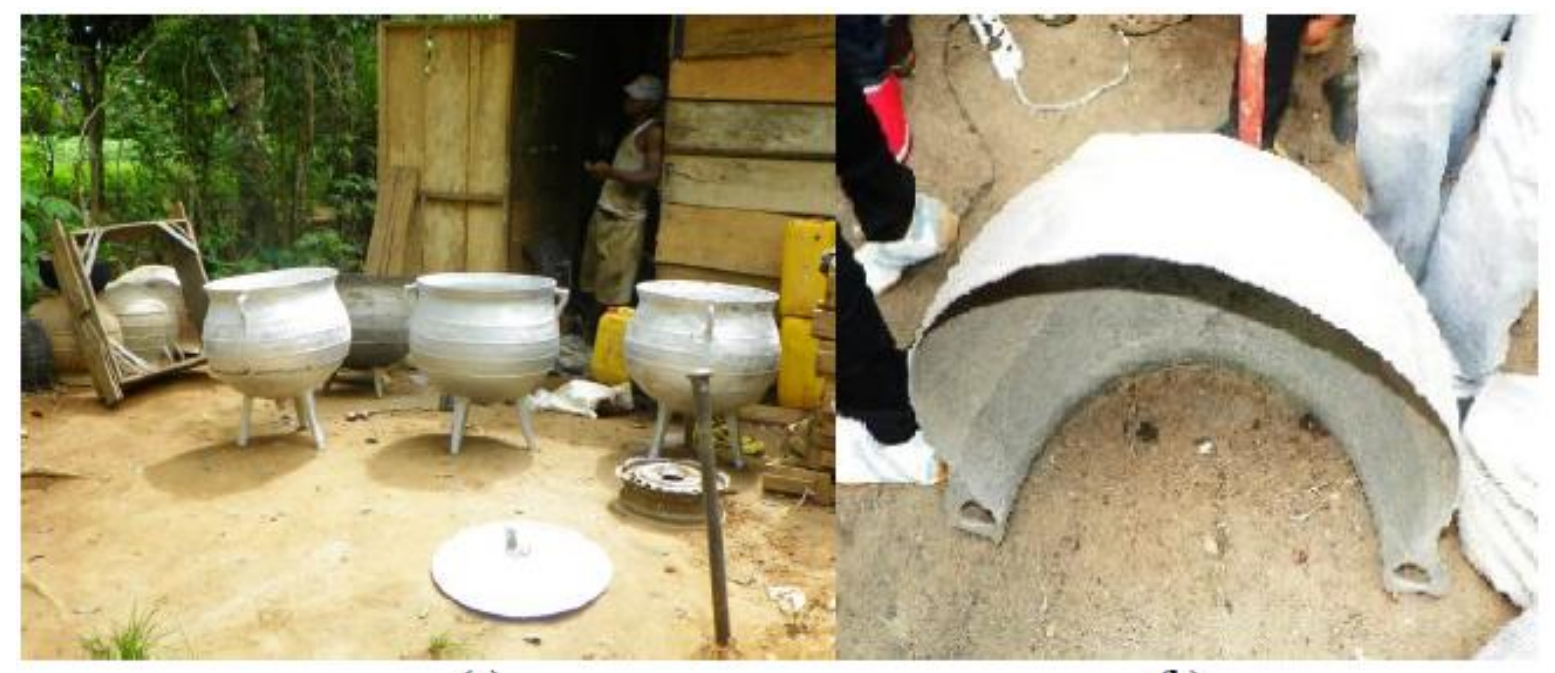

(a) (b)

Plate6(a-b): Mould and Finished Products (Iron Pots)

\section{DISCUSSION: IMPLICATIONS OF TRADITIONAL ARTS AND CRAFTS INDUSTRIES IN ISUOCHI}

The implications of traditional arts and craft in Isuochi are discussed under economic, socio-cultural, religious and political impacts.

\subsection{Economic Impact}

Traditional arts and craft industries have played a very important role in society. Arts and crafts industries serve as a major source of revenue generation to host communities. The products of the craftsmen are sold and this improves their living standard. The agricultural sector in Isuochi society is one of the areas that has benefited so much from the arts and crafts industry. This is so because blacksmiths produce most of the farm implements used by the subsistence farmers. Farm tools like cutlass; hoes etc are used in a bush clearing, land cultivation, farm weeding and other agricultural practices. Profits are usually made from the sale of agricultural products like yam, maize, palm oil, cassava etc and forest resources like timber.

The impact has been felt on food production and hunting activities in the study area. The implements used by the hunters such as metal traps, spear, matchet, knife etc are all fashioned by blacksmiths. Mats and baskets are used to store and preserve agricultural products like onions, pepper etc; which provides enough food for the families in time of scarcity. Agricultural surplus also creates leisure and industrial production. Again, the local roofing materials are in high demand for building and other purposes. Most of the inhabitants of the society cannot afford the modern architectural style of building; hence, their dependence on local roofing materials to support their traditional building (ulo aja).

\subsection{Socio-Cultural Impact}

The impacts of traditional arts and crafts industry on the socio-cultural activities of Isuochi people cannot be overemphasize. Musical instruments used like a drum, notched flute (oja) wooden gong (ekwe), masks, etc are all fashioned by carvers and blacksmiths. Musical instruments are showcased mostly during traditional festivals like traditional marriage ceremonies, burials, age-grade meeting etc. Metal and wood, which are the artists' main materials per excellence has been intimately connected with their social and cultural histories of countless African groups.

Furthermore, woodcarvers and blacksmiths in Isuochi produce objects, which form an important aspect of the socio-cultural activities. They carve masks, which are worn during traditional festivals. 
A very good example is the masquerade mask, which according to Miachi, T.A. (1988) is a structural entity, dressed totally or partially concealed wearing a mask (made of wood raffia or cloth, which covers the face) and believed by most Africans to emanate from and belong to the world of the costume spirits." Most of the masquerades in Isuochi wear wooden masks carved by Isuochi artisans. Today, traditional music and dancers usually accompany masquerades in Isuochi. This is inconsonant with Aniakor (1976) who postulate that "masks" requires a total musical environment (especially when socially-oriented) in the kinaesthetic sense to be fully functional.

\subsection{Religious and Political Impacts}

Similar to the rest of the world, Isuochi arts and crafts industries are closely linked to religion and politics. The carver creates objects that are well organized and appreciated in the context of religious worship. These objects include sacred figures, which are used to adorn shrines, reliquary figures, charms, figures stools are used for initiation into cults, dance staff, apparatus of divination etc. Most of which provides aspects of African life and religious genies.

There are many works of arts in Isuochi society, which are made in honour of different deities (gods) called 'arusi'. They served and worshipped these deities, which served as intermediaries or representatives of the supreme being "Chukwu". Most of these images were carved from sacred trees like the "Oji" tree and the people believed that the gods, which are omnipresent, omnipotent and sacred posses animistic powers. The worshippers of the gods create special sacred grove as places of abode for the deities (Anadu, 1988) having believed that the gods protect and defend them during the time of wars and as well as make their land fertile. The arts and craft industries of Isuochi are also associated with political institutions in society. This was observed by Aniakor (1976) that art objects can be perceived relatively to each political system, which provides a minor image of the concept, applications and meaning of leadership in African societies.

In the "Ozo" title taking, some wooden objects like wooden staffs, carved stools etc serve as an emblem of political and ritual authorities of the "ozo" institution. These objects are fashioned by Isuochi woodcarvers and craftsmen. Another significant and important object that is used in the political institution of Isuochi society is masks heads and masquerades. As rightly argued by Odita (1970) Igbo masks may assume the authority of judgment, jury and met out punishment, including the death sentence. They may severely punish not only offences against the society itself; but also deviants from the common rules and regulation (Odita, 1970). The judgments of masquerades in Isuochi are final because they are regarded as the judgment of the spirits, which are above that of humans and as such are feared and respected.

\section{FACTORS AFFECTING THE SURVIVAL OF THESE ARTS AND CRAFTS INDUSTRIES}

Western culture has been a major factor that has hindered the growth of arts and crafts industries in Isuochi community. It has been noted that contacts with Europeans opened the Igbos to new realities; new kind of opportunities, there began to emerge some awareness that traditional lifestyles would no longer be useful in the new society. Hence, the notion of occupational stratification was matured. This is a systematic hierarchy of social position whose occupation is treated as superior, equal or inferior relations to one another in socially important respects" (Ali, 1998). Also, Haaland (1985) sees it as a concept, meaning constraint, preventing certain occupational classes from assuming other identities and restricting people from taking up such occupations.

The advent to the European system of salaried employment known as "white-collar job" attracted most of the craftsmen as well as people of other occupations. They believed that white-collar jobs are more lucrative and provide easy and sufficient money for living than their traditional crafts could do. This had a negative effect on the development of traditional arts and crafts industry as only a few people are left to practice it -mostly the aged.

In addition, the Europeans brought their sophisticated products and new technologies as they settle within society. The products, which includes plastic plates and cups, glass plates and cups, spring beds and foam etc, are preferred to the peoples' locally made baskets, mats etc. This led to a decline in the production and demand for traditionally made goods. 
Illiteracy is also one major problem that affected the growth and development of traditional arts and craft. Most of the craftsmen cannot read, nor write; hence, they, remain with their old fashion method of production (carving, basket/mat making) and also, stick to their old and crude tools. Because of illiteracy, their knowledge is jealously guarded and thus, is not open to research works for documentation. This lead to a loss of knowledge and skills towards the promotion of traditional arts and crafts industry.

Lack of basic social and infrastructural amenities is also another problem that hinders the growth and development of traditional arts and crafts. Basic infrastructures such as electricity, portable drinking water, good roads, health care centres and recreational centres are lacking in rural areas where the production of these crafts takes place. Even where they do exists; they are in a very deplorable slice. This has encouraged rural to urban migration - migrants are in search of a good life to the detriment of traditional arts and crafts industry.

Another major factor is poverty. Most of the craftsmen in Isuochi are very poor and lack funds to embark on fulltime specialized crafts projects. Most of them cannot obtain loan from financial institutions because they are not qualified and in most cases do not have the securities that will serve as collateral as required by banks before a loan is granted. Lack of money makes it impossible for them to purchase raw materials, tools and modern equipment and to build workshops to help them produce these traditional arts and crafts in large scale.

Government attitude, ecological and religious problems are also a problem that inhibits the growth and development of the arts and crafts industry. Most often, traditional craftsmen in Isuochi do not receive incentives from the government either in the form of grants, loans, Seminar/ workshops etc to encourage and facilitate the production of traditional arts and crafts. Ecological problems such as erosion, landslides etc also hinder the practice of traditional arts and crafts in Nigeria generally. Extreme rainfalls cause erosion, which causes the decay of wooden objects. Also, extremely dry conditions also cause cracks on objects made of wood. which if not taken care of, leads to the total disintegration of the objects. With the introduction of Christianity, there was a drastic decline in the production of some of these cultural objects that served a religious purpose as they were considered to be fetish.

\section{CONCLUSION}

Arts and crafts are man-made objects that require manual dexterity or the application of artistic skill to accomplish. Such products may be in the form of a wooden mask, basket, and clay pots. Such art and craft are appreciated for their religious functions while others are for their aesthetic functions. Some scholars are of the view that art and craft serve as an important reference that helps them to share a common value and have a sense of consciousness of oneness.

Art and craft in Nigeria today have not been fully harnessed by the government to meet the development needs of the nation. Art and craft are still left in the hands of individuals or at least to family members who monotonously pass on the tradition to younger generations without making any significant impact on the host community.

Traditional art and crafts in Isuochi have been an age-long tradition passed on from one generation to another. In addition, the aspects of traditional arts and crafts are being threatened by extinction through gross neglect by the indigenes of Isuochi, as well as, lack of encouragement and support by the government.

Traditional arts and crafts are indicative of our past, pointing in both the directions of where we are coming from and where we are going. Unless something drastic is done in the case of traditional arts and crafts in Isuochi, the future of the indigenous knowledge and technology inherent in the craft remains bleak.

\section{REFERENCES}

[1] Abia census board (1990) 1990 Population Counts. Ministry of Land and Survey: Abia State.

[2] Abia State Ministry of Agriculture (2004) Classification of Crops in Abia State. Crop Units, Ministry of Agriculture, Abia State

[3] Achebe, C. (1983) The Trouble with Nigeria. Enugu Fourth Dimension Publishers. 
The Isuochi Artisans: Implications of Traditional Arts and Crafts of Isuochi People for Tourism Development in Abia State, Nigeria

[4] Advanced Dictionary (2006) Sixth Edition.

[5] Afigbo, A.E (1981) Rope of Sand: Studies in Igbo History and Culture. Nsukka: University of Nigeria, Nsukka Press.

[6] Ali, V.E. (1998) Occupation Stigmatization Implications for the development of African Traditional Arts and Culture. Nsukka Journal of the Humanities; No. 9, June 1998.

[7] Agbolahor, J.Nd Ukhurebor, A.R (2006) Tourism and National Development. In Issues in Tourism Planning and Development. Enugu: Afro-Orbis Publication Ltd. Pp. 86-95

[8] Anochirimonyeari, M.N (1990) Atta the Land of Our Birth. Ben Olu Cashman and Co. Printers Ltd, Lagos.

[9] Aniakor, C.C. (1976) The Broad Synthesis of African Arts: A Survey of their Significant Aspects. Ikoro: Vol.3 No 2 Pp. 9-45

[10] Basdan, G.J. (1966) Among the Igbo's of Nigeria. London Frank Cass and Co. Ltd.

[11] Encyclopedia Britannia (2007) Vol 30, International edition

[12] Ekpo, E. (1980) Two Thousand Years of Nigerian Art. London.

[13] Ezeh, P.J. (2000) A Survey of Socio-Anthropological Thoughts for African Students. Enugu: Echirisi and Co.

[14] Eze-Uzomaka, P.I. (2006) Tourism and Community Development. In Okpoko Pat Uche (ed) Issues in Tourism Planning and Development. Enugu: Afro-Orbis Publication Ltd.

[15] Emejue, P.N. (1973) Igbo Traditional Sculpture Centred in Orumba. Unpublished B.A Thesis. Department of Fine and Applied Arts. University of Nigeria, Nsukka.

[16] Fischel, E. (1982) An Introduction to Meal and Metallurgic Techniques in African Art. In the Art of Metal in Africa. New York: The African American Institute Pp.13-16.

[17] Goucher, C.L. (1990) African Hammer, European Anvil: West African iron Technology in Atlantic Trade. Cultural Resources Management, An African Dimension. West African Journal Archaeology. Vol 20; Pp.200-208.

[18] Goulet, G. (1968) On the Goals of Development, Cross Current, 18, Pp. 387-405.

[19] Haaland, R. (1985) Iron Production, Its Socio-Cultural Context and Ecological Implications. In African Iron Working-Ancient and Traditional. Oslo: Norwegian University Press Pp. 50-72.

[20] Isichie, E. (1976) A History of Igbo People. London: Macmillan Press Limited.

[21] Jabbe, A.D.B. (2004) Crafts as Souvenir for Cultural Tourism. In Akinbogun, T.L, (ed.) Nigeria Crafts and Techniques. Akure: Nigerian Crafts Forum, Federal University of Technology, Akure.

[22] Miachi, J.A. (1988) The Political Process in Igala land: Some Nigerian People. West African Journal Archaeology. Vol. 18: Pp.157-179.

[23] Microsoft Encarta (2009) 1993-2008 Microsoftware Corporation. All rights reserved.

[24] Ministry of Land and Survey Umuahia (2002) Map of Abia State.

[25] Nwabueze, N.A. (2005) Traditional Crafts and Industries in Isseke, Ihiala L.G.A. of Anambra State: An Ethnoarchaeological Study. A Bachelor of Arts Project in the Department of Archaeology and Tourism, University of Nigeria, Nsukka. Pp. 8-59.

[26] Nwaunobi, C.O. (1992) African Social Institutions. Nsukka: University of Nigeria Press.

[27] Nzei, A.A. (1994) Salvage Ethnography. The Institute of African Studies. University of Nigeria Nsukka. West African Journal of Archaeology Vol 24: Pp.80-93.

[28] Ogunagha, P.A. (1988) The Igbo People Some Nigeria people's. West African Journal Archaeology Vol. 18: Pp.127-142.

[29] Oguntoyinbo, T.S (1978) A Geography of Nigeria Development. Heinemann Education Books.

[30] Okpoko, A.I. and Okpoko, P.U. (2002) Tourism in Nigeria. Enugu: Afro-Orbis Publications Ltd.

[31] Okpoko, P.U. (2006) Issues in Tourism Planning and Development. Enugu: Afro-Orbis Publication Ltd Nsukka.

[32] Omeje, P.U. (2006) Tourism and Development Corporation. In Okpoko, P.U. (ed). Issues in Tourism Planning and Development. Enugu: Afro-Orbis Publication Co. Ltd. Pp.70.

[33] Otite, O. and Oginwon, W. (1979) An Introduction to Sociological Studies. Heinemann Educational Books (Nig). Ltd, Ibadan, Pp.23.

[34] Steck, B. (1999) Sustainable Tourism as a Development Option Guide for Local Planners, Developers and Decision Makers. $2^{\text {nd }}$ edition. Federal Ministry for Economic Development. Germany.

[35] Strides, G.T. and Ifeka, C. (1980) People and Empires of West African. West African in History 10001800, Lagos; Thomas Nelson Limited. 
The Isuochi Artisans: Implications of Traditional Arts and Crafts of Isuochi People for Tourism Development in Abia State, Nigeria

[36] Smith, D.M. (1977) Human Geography: A Welfare Approach. Arnold, London.

[37] Umekekwe, O.C. (1998) An Ethnographic Evaluation of Traditional Arts and Industries in Ebenesie. An Unpublished B.A. Thesis, Department of Archaeology, University of Nigeria, Nsukka.

[38] World Book encyclopedia (2003) www.worldbookencyclopedia.com Accessed 14/07/2011

Citation: Emeka E. Okonkwo, et.al. "The Isuochi Artisans: Implications of Traditional Arts and Crafts of Isuochi People for Tourism Development in Abia State, Nigeria". International Journal of Research in Tourism and Hospitality (IJRTH), vol 6, no. 1, 2020, pp. 1-15. doi: http://dx.doi.org/10.20431/24550043.0601001.

Copyright: (C) 2020 Authors. This is an open-access article distributed under the terms of the Creative Commons Attribution License, which permits unrestricted use, distribution, and reproduction in any medium, provided the original author and source are credited. 